\title{
King Stephen
}

\section{New}

R. H. C. Davis. This is a life and history of the reign of King Stephen, grandson of William the Conqueror. Mr. Davis has used contemporary documents to clarify the events of a most confused era. He compensates for the deficiencies of the chronicles by studying in detail the more than 1,000 charters of King Stephen and his rivals, and a coherent and accurate picture of the times emerges.

$\$ 5.00$

\section{The Elizabethan Puritan Movement}

Patrick Collinson. The Elizabethan puritan movement arose from discontent with the religious settlement of 1559 , and the desire among many of the clergy and laity for further reformation. Mr. Collinson implicates the nobility - including the Earl of Leicester - the country gentry, London citizens, and above all the godly energetic preachers and a genius of conspiracy, John Field. The book demonstrates for the first time both the gravity and the extent of the movement.

$\$ 10.00$

\section{FORTHCOMING, SUMMER 1967}

\section{Whig Organization in the General Election of 1790}

Selections from the Blair Adam Papers

Edited by Donald E. Ginter. The letters in this volume comprise correspondence to and from William Adam, political manager of Whig opposition in the general election of 1790 . They indicate the scope and quality of Whig activity, revealing that Adam and the Duke of Portland were leading figures in party organization and funding of a number of candidates.

$\$ 7.00$

\section{from California}

UNIVERSITY OF CALIFORNIA PRESS • Berkeley 94720 


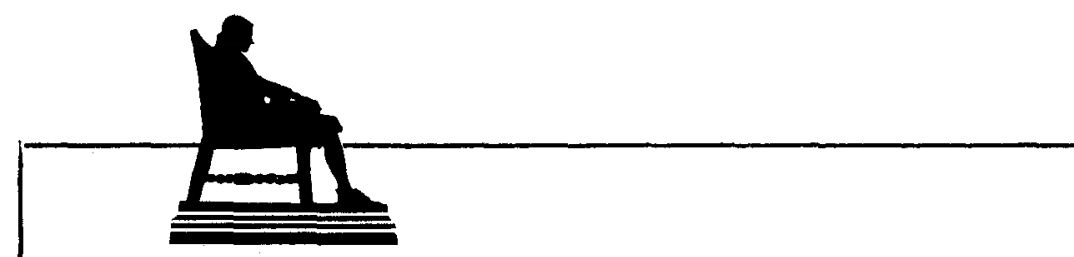

THE BENEVOLENT MAN

A Life of Ralph Allen of Bath By BENJAMIN BOYCE

Ralph Allen of Bath (1693-1764), the original of "Squire Allworthy" in Fielding's Tom Jones, was a fine example of the benevolent man, the type of generous, amiable Christian gentleman often idealized in eighteenth-century prose. The first complete account of his many-faceted life provides, in addition, a history of Bath during its inception as a fashionable spa. $\$ 7.95$

\section{THE WILBERFORCES AND HENRY MANNING}

\section{The Parting of Friends BY DAVID NEWSOME}

Samuel, Robert, and Henry Wilberforce, with their brother-in-law Henry Manning, are the central figures in this powerful narrative of religious conflict in early Victorian England. The author portrays the buoyant hopes of this influential circle before Newman's secession to Catholicism and its tragic dissolution in the years that followed. "Learned and brilliant study ..."-The Sunday Times (London). Belknap Press. $\$ 12.00$

\section{THE LETTERS OF MRS GASKELL}

\section{Edited by J. A. V. CHAPPLE and A. POLLARD}

Covering the years 1832-1865, this volume includes all of Mrs. Gaskell's letters the editors could trace. Valuable as the record of a significant writer, they also contain a wealth of information about a host of major Victorian literary figures. 2 vols., $\$ 22.50$

\section{MRS. GASKELL}

\section{Novelist and Biographer By ARTHUR POLLARD}

In this systematic critical examination of her work, including a biographical survey and summary, Mrs. Gaskell emerges as a figure of some significance in the annals of the English novel and as a writer who clearly deserves rereading today. $\$ 5.50$ 


\section{WORDSWORTH}

The Chronology of the Early Years, 1770-1799 BY MARK L. REED

Based on unpublished as well as published materials, this is the first volume of an exhaustive chronology of the life and works of Wordsworth. An invaluable reference tool, it provides a rapid means of access for any type of study making use of either the dates or relative order of Wordsworth's writings or personal experiences. $\$ 9.00$

\section{THE OREGON QUESTION}

Essays in Anglo-American Diplomacy and Politics By FREDERICK MERK

In these essays, one of America's most distinguished historians traces the controversy extending from the War of 1812 to 1846 between the United States and Great Britain over the Oregon Country, and examines the six negotiations held at intervals over these years to settle the dispute. Four of the essays and an important introduction are published here for the first time. Belknap Press. $\$ 7.95$

\section{TRADE AND EMPIRE}

The British Customs Service in Colonial America, 1660-1775

\section{BY THOMAS C. BARROW}

Mr. Barrow presents the first analysis of the operation and organization of the colonial customs service from its inception in 1673 to its collapse in 1775. His study of the institution that was one of the chief causes of colonial discontent sheds new light on a pivotal era in Anglo-American history. $\$ 8.00$

\section{THE VOCAL SONGS IN THE PLAYS \\ OF SHAKESPEARE}

\section{A Critical History By PETER J. SENG}

Presenting authoritative texts for the songs found in the plays of Shakespeare and discussing their sources, Mr. Seng provides a critical history of the songs from 1709 to the present, considers their dramatic function, and locates the scores in modern editions. $\$ 8.95$

\section{ARVARD}

\section{UNIVERSITY PRESS}




\section{The \\ Uatbolí}

Official Organ of the

American Catholic Historical Association

$$
\left[\begin{array}{c}
\text { A QUARTERLY JOURNAL } \\
\text { Founded in } 1915
\end{array}\right]
$$

Martin R. P. McGuire

Johi Tract Eluis

\}Associate Editors

Robert F. Trusco

Managing Editor

Annual Subscription: $\$ 7.00$, U.S., Canada and Foreign

The Cathalic Wistorital hebiew

THE CATHOLIC UNIVERSITY OF AMERICA PRESS

Washington, D. C. 20017

\section{A Quarterly Published by Authority of the General Convention \\ H I S T O R I C A L \\ M A G A ZI N E \\ OF THE \\ PROTESTANT EPISCOPAL CHURCH}

U.S.A. $\$ 1.50$ the Copy $-\$ 6.00$ the Year

A journal of the historical narrative, bibliography, documents and interpretation in the field of the Protestant Episcopal Church and the Anglican Communion.

Order from:

BOX 2247, AUSTIN, TEXAS 78767 


\section{Launching the monumental}

\section{DELACORTE WORLD HISTORY SERIES...}

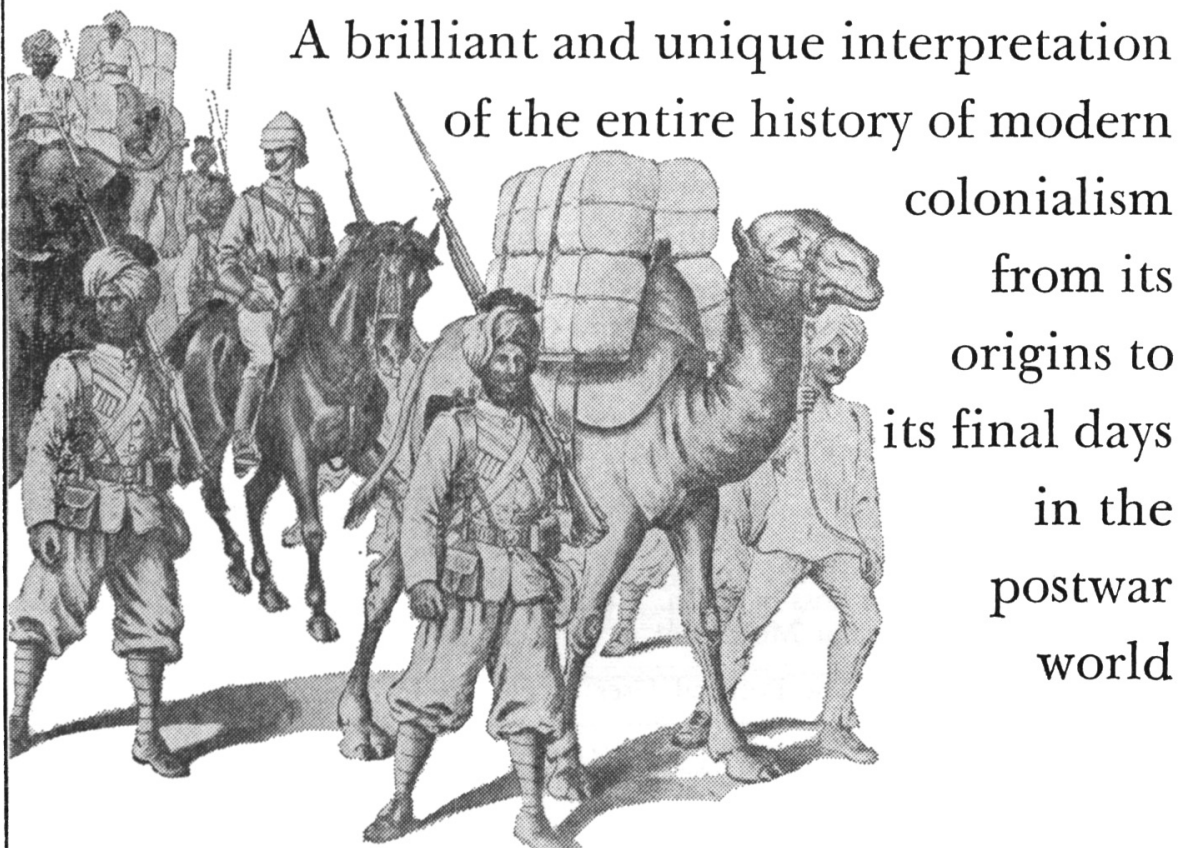

The Colonial Empires by the noted scholar, D. K. Fieldhouse is the first major examination of colonialism to place the subject in total perspective.

Unlike earlier studies which have dealt with the possessions of a single power, this book examines the strengths and weaknesses of every colonial system, and it answers the central questionswhy colonies were acquired, how they were governed, and why they eventually disappeared.

Original in its concepts, exciting in its narrative, and impeccable in its scholarship, this book is a worthy introduction to the forthcoming thirty-five volume Delacorte World History.

\section{THE COLONIAL EMPIRES}

By D.K. FIELDHOUSE, Beit Lecturer in the History of the Commonwealth and Fellow of Nuffield College, Oxford. Illustrated with remarkable photographs, drawings and paintings. $\$ 8.00$, now at your bookstore. DELACORTE PRESS

Among the titles in preparation:

THE NEAR EAST: THE EARLY CIVILIZATIONS

THE GREEKS AND THE PERSIANS

HELLENISM AND THE RISE OF ROME

THE HIGH MIDDLE AGES

SOUTH AND CENTRAL AMERICA: THE COLONIAL PERIOD 


\section{PAST AND PRESENT}

First published 1952.

Forthcoming articles in No. 36 (April 1967 issue) will include:-

Jobn Briscoe: Rome and the Class Struggle in the Greek States 200-146 B.C.

Hans Baron: Leonardo Bruni: "Professional Rhetorician" or "Civic Humanist"?

Gerald Strauss: Protestant Dogma and City Government: the Case of Nuremberg

Clive H. Church: The Social Basis of the Central Bureaucracy in France under the Directory 1795-1799

D. J. Rowe: The London Working Men's Association and the "People's Charter"

Susan Budd: The Loss of Faith. Reasons for Unbelief among Members of the Secular Movement in England 1850-1950

Olive Anderson: The Political Uses of History in Mid NineteenthCentury England

Debates.

Recent issues have included:

Peter Brunt: The Roman Mob (December 1966)

Denis Twichett: Chinese Social History from the Seventh to the Tenth Century: The Tunhuang Documents and their Implications (December 1966)

Jerrold E. Seigel: "Civic Humanism" or Ciceronian Rhetoric? (July 1966)

James Joll: The 1914 Debate Continues (July 1966)

Lawrence Stone and Alan Everitt: Social Mobility in England 1500-1700 (April 1966)

M. Malowist: The Western Sudan in the Middle Ages (April 1966)

Annual Subscription $25 /-$. (\$4.25).

Single issue $15 /-$. (\$2.50)

Reduced Annual Subscription for Students 15/-. (\$2.50)

All past issues available - Classified Table of Contents free on request.

Write: Business Manager,

PAST AND PRESENT, Corpus Christi College, Oxford, England 


\section{THE NEW ZEALAND JOURNAL OF HISTORY}

The NEW ZEALAND JOURNAL OF HISTORY is a new journal to be edited by Keith Sinclair and published by the University of Auckland. It will appear in April and October commencing in 1967.

The JOURNAL will publish articles on all aspects of history, but it has a special interest in the history of New Zealand, Australia, Southeast Asia and the Pacific.

Early issues will include articles on Thomas Kendall, Sir George Grey, Ettie Rout, the Round Table groups in New Zealand and the causes of the two World Wars.

SUBSCRIPTION RATE payable in advance, post free:
$£ 1.10 .0$ or $\$ 3$ N.Z.
$£ 1.12 .6$. sterling
\$4 Australian
$\$ 4.50$ U.S.A.

Subscriptions and all business correspondence should be addressed to:

The Business Manager,

New Zealand Journal of History,

University of Auckland, P.O. Box 2175, Auckland

ARTICLES:

\section{THE HISTORICAL JOURNAL}

Editor: F. H. HINSLEY

Contents of Volume IX, No. 3, 1966

I. The Lisle-Seymour Land Disputes: a Study of Power and Influence in the 1530s. By M. L. Bush.

II. In Pursuit of Heresy: Spanish Diplomats versus Spanish Heretics in France and England during the Wars of Religion. By Paul J. Hauben.

III. The Ideological Context of Hobbes's Political Thought. By Quentin Skinner.

IV. The Civil List in Eighteenth-Century British Politics: Parliamentary Supremacy versus the Independence of the Crown. By E. A. Reitan.

V. The Two Societies: a Study of Town Life in Nineteenth-Century Ceylon. By Yasmine Gooneratne.

VI. The Strategic Background to the Anglo-Russian Entente of August 1907. By Beryl J. Williams.

REVIEW ARTICLES:

1. Pre-Industrial Society. By Edward Miller.

2. Friedrich von Holstein. By J. C. G. Röhl.

OTHER REVIEWS

Subscription price per volume of 3 parts $\$ 9.50$

Copies may be ordered from your bookseller or from

CAMBRIDGE UNIVERSITY PRESS

32 East 57tb Street, New York, N. Y. 10022 


\section{Pollbooks: How Victorians Voted}

J. R. VINCENT

The first book to collate and interpret Victorian pollbooks reveals, among other findings, that the distribution of wealth produced voting patterns only slightly related to social strata.

All available statistics, derived from analysis of over 150 elections between 1826 and 1872, are tabulated at the end of the book.

$\$ 9.50$

\section{The Making of the Second Reform Bill}

\section{F. B. SMITH}

A full account of the passing of the second Parliamentary Reform bill in 1867, and of the defeat of its predecessor in 1866. The narrative is set in a context of rapid social change and popular agitation.

$\$ 10.50$

\section{The Agrarian History of England and Wales}

H. P. R. FINBERG, General Editor

This new project, when completed, will comprise a complete social and economic history of rural England and Wales from the Neolithic period to the early twentieth century.

Volume IV, 1500-1640, edited by Joan Thirsk, is the first to be published.

Volume IV, $\$ 25.00$

\section{Race Relations in the British Commonwealth and the United Nations}

LORD CARADON

The Smuts Memorial Lecture, 1966

95 cents

Jawaharlal Nehru: The Struggle for Independence

LORD BUTLER

The First Jawaharlal Nehru Memorial Lecture, 1966

95 cents 


\section{John Locke: Two Tracts on Government}

Edited by PHILIP ABRAMS

The first publication in English of two uncompromising defenses of authoritarian government written by Locke in 1660, and suppressed by him.

The book includes a long essay by Dr Abrams on the significance of these tracts in Locke's philosophical development.

\section{British Broadcasting and the Danish Resistance Movement, 1940-1945}

\section{JEREMY BENNETT}

A study of the wartime broadcasts of the B.B.C. Danish Service, intended to provide accurate news, project British views into Denmark, and support the Danish Resistance Movement.

The author describes the organization and work, discusses policies of the B.B.C. and its propaganda advisers, and analyzes the effects of the broadcasting. $\quad \$ 10.00$

\section{Fenland Chronicle}

\section{SYBIL MARSHALL}

Recollections of William Henry and Kate Mary Edwards collected and edited by their daughter, Sybil Marshall, and illustrated with 70 drawings by Ewart Oakeshott.

These personal memories, going back into the 1870 's, picture in figurative, easily readable dialect the distinctive way of life and the strongly individual people of the English fenland country. $\$ 8.50$

\section{CAMBRIDGE UNIVERSITY PRESS}

32 East 57th Street, New York, N.Y. 10022 


\title{
English Historical Documents
}

\section{Volume V: 1485-1588}

\author{
Edited by C. H. WILLIAMS, \\ Professor Emeritus, University of London
}

This volume in the English Historical Documents series, which is under the general editorship of David C. Douglas, covers the years from the accession of Henry VII to the death of Mary. It illustrates the interconnection between the constitutional, ecclesiastical, and social movements which marked this critical period in England's history. Like the other volumes in the series, a comprehensive body of material relating to the period is presented, with editorial comment designed to make the material intelligible rather than to present a critical evaluation.

Following a general introduction there are sections, consisting of extensive contemporary documents, on: historical writings, impressions and descriptions of the countryside, the structure of society, the commonweal, leaders in society, government, administration, legal records, government theory, opinions on the King's Private Matter, religious controversies and doctrines, daily life in town and country, industry, economic conditions, and education. Each section is preceded by its own introduction.

$\$ 23.50$

Oxford University Press / New York 


\section{Survey of London}

\section{Volumes XXXIII and XXXIV THE PARISH OF ST. ANNE, SOHO}

\section{General Editor, F. A. W. SHEPPARD}

Scattered throughout London are many of the finest buildings in England: churches, royal palaces, noblemen's mansions, private houses and public buildings. Many of them are the work of great architects and some of them have close associations with the great men of the past. The purpose of the SURVEY OF LONDON is to provide a permanent record of all these buildings.

Starting with the first volume in 1900 , there have been thirty-four volumes covering one-third of the old County of London. Each volume traces the history and describes the important buildings of a particular area, with numerous illustrations from photographs, prints, and measured drawings. The historical and architectural texts are the result of first-hand research and inspection. These two new volumes describe Soho, the most famous of London's cosmopolitan quarters. Many of the buildings covered have been destroyed, some of them a long time ago. $\$ \$ 40.35$

\section{Oxford University Press / New York}




\section{NEW PERSPECTIVES}

\section{J. Bartlett}

\section{CASTLEREAGH}

As architect of the Quadruple Alliance, Castlereagh engineered the defeat of Napoleon; as founder of the Concert of Europe, he established peace for a generation. This life of the much-vilified Foreign Secretary $\rightarrow$ the first full-scale biography in thirty years - rates him as a world statesman of the first order.

$\$ 5.95$

\section{John Vincent \\ THE FORMATION OF THE BRITISH LIBERAL PARTY}

Working from original sources - poll-books, the records of workingmen's organizations and the private papers of leading figures - John Vincent sees the rise of the Liberal Party not only as the triumph of industrialism, but the fusing of two sequences: the growth of liberal constituencies and of a responsive leadership in Parliament. $\$ 6.95$

\section{Karl W. Deutsch, Lewis J. Edinger,} Roy C. Macridis and Richard L. Merritt FRANCE, GERMANY AND THE WESTERN ALLIANCE

Crucial opinions and predictions on the future of Europe: a summary of 312 in-depth interviews with members of "elite" groups in France and Germany.

$\$ 6.95$

\section{Eric Williams BRITISH HISTORIANS AND THE WEST INDIES}

With a Preface by Alan Bullock. A highly critical dissection of the accepted historiography of the West Indies from Stubbs to Carlyle.

$\$ 4.95$

CHARLES SCRIBNER'S SONS

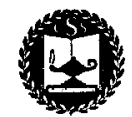

New York 


\section{THE JOURNAL OF BRITISH STUDIES TRINITY COLLEGE HARTFORD, CONNECTICUT}

The Journal of British Studies, founded in 1961, is published at Trinity College under the auspices of the Conference on British Studies. It was the result of the imaginative generosity of a Trinity alumnus, Frederick E. Hasler (Hon. LL.D. 1957) who contributed funds to the College for the specific purpose of establishing a learned periodical in the field of British history. Several Trinity alumni subsequently contributed to the fund and Trinity College now supports the publication of the Journal.

The Conference on British Studies is the official organization in the United States and Canada of scholars working in the field of British history and culture; its status as such is recognized by the American Historical Association of which it is an affliate. Its nearly eight hundred members are drawn from forty-eight states and five provinces. It convenes twice each year at New York University, its permanent headquarters.

The Conference awards a prize triennially for the best first book by an American or Canadian scholar.

The Conference sponsors a considerable publications program. It publishes the Journal of British Studies at Trinity College; the British Studies Intelligencer, a newsletter, at Kansas State University, Manhattan, Kansas; Studies in British History and Culture, an annual series of monographs, at the University of Bridgeport, Connecticut; Archives in British History and Culture, an annual series devoted to the publication of documents, at West Virginia University, Morgantown; and Current Research in British Studies, a quadrennial survey of research in progress in the United States and Canada, the next edition of which will appear in 1968 at Southern Methodist University. The Conference has undertaken to sponsor a series of bibliographical handbooks which will be published by the Cambridge University Press.

In addition to the Conference on British Studies, there are three affiliates: the Pacific Coast Conference on British Studies, the Midwest Conference on British Studies, and the Southern Conference on British Studies. Each of these vital autonomous groups has its own officers, program, and other activities. There are also local groups centered in San Francisco, Los Angeles, Detroit, and Pittsburgh.

The Journal of British Studies appears twice in the academic year, in the autumn and in the spring. The annual subscription is $\$ 5.00$. Checks for subscriptions and enquiries concerning advertising rates should be directed to the Business Manager, British Studies, Box 1315, Trinity College, Hartford, Connecticut, 06106.

Volume VII, No. 1 will be published in November, 1967. 


\section{CONFERENCE ON BRITISH STUDIES PRIZE}

The Conference on British Studies will award its fourth triennial prize of three hundred dollars in November, 1969. The prize will be given for the best book published between January 1, 1966 and December 31, 1968, by an American or Canadian scholar. It must be the author's first book. Its subject must lie either within the field of English History or Commonwealth History. The prize will be awarded by a panel of judges consisting of:

Arthur B. Ferguson, Duke University

John S. Galbraith, University of California

Thomas Peardon, Columbia University

Enquiries and recommendations should be addressed to the Chairman, Professor Arthur B. Ferguson, Duke University, Durham, North Carolina.

The past recipients of the prize are: Philip P. Poirier, Ohio State University, 1960; C. Warren Hollister, University of California, 1963; Melvin Richter, Hunter College, 1966. 